\title{
Morphophysical and biochemical traits involved in maize grain varietal susceptibility to the maize weevil, Sitophilus zeamais (Coleoptera, Curculionidae)
}

\author{
Déthié Ngom ${ }^{(1)}$, Marie-Laure Fauconnier ${ }^{(2)}$, Paul Malumba ${ }^{(3)}$, Cheikh Thiaw ${ }^{(4)}$, \\ Thierry Brévault ${ }^{(5,6)}$, Mbacké Sembène ${ }^{(1,5)}$
}

(1) Cheikh Anta Diop University. Sciences and Technics Faculty. Department of Animal Biology. PO Box 5005. Fann, Dakar (Senegal).E-mail: dethie.ngom@ucad.edu.sn

(2) University of Liege - Gembloux Agro-Bio Tech. Department of AgroBioChem. Avenue de la Faculté, 2. BE-5030

Gembloux (Belgium).

(3) University of Liege- Gembloux Agro-Bio Tech. TERRA Teaching and Research Center. Avenue de la Faculté, 2B.

BE-5030 Gembloux (Belgium).

(4) University El-Hâdj Ibrahima NIASS of Sine Saloum. UFR Agronomy and Crop Production. PO Box 55. Kaolack

(Senegal).

(5) Research Institute for Development. BIOPASS. PO Box 1386. Bel-Air, Dakar (Senegal).

(6) CIRAD. UPR AIDA. F-34398 Montpellier (France).

Received 2 June 2020, accepted 9 february 2021, available online 5 March 2021.

This article is distributed under the terms and conditions of the CC-BY License (http://creativecommons.org/licenses/by/4.0)

Description of the subject. Maize (Zea mays L.) is a major staple food providing nutrients for humans and animals worldwide. In Sub-Saharan Africa, maize is stored to ensure food resource availability throughout the year. However, stored-product pests such as the maize weevil, Sitophilus zeamais (Motsch.) (Coleoptera; Curculionidae) can cause huge grain losses.

Objectives. This study aimed to assess the oviposition preference of Sitophilus zeamais over maize varieties commonly cultivated in Senegal and the effect of grain morphophysical and biochemical characteristics on their susceptibility to the maize weevil.

Method. Twenty-five S. zeamais pairs (M/F) were placed in the center of an arena at equal distance of small heaps of maize grains (30 g) from nine maize varieties. Adult abundance, damaged grains, grain weight loss, and progeny were confronted to grain characteristics (phenolics and ferulic acid content, hardness, brightness, color and size of grains).

Results. Susceptibility to the maize weevil varied significantly among maize varieties. Synth-9243 was the most susceptible variety with greatest damaged grains $(10.5 \pm 2.3 \%)$, grain weight loss $(2.3 \pm 0.6 \%)$, and progeny $(17.3 \pm 3.8$ adults). The least susceptible varieties were Across-Pool, SWAN, Obatampa, and Tzee-Yellow. Grain characteristics such as phenolics and ferulic acid content were negatively related to susceptibility, but other constituents may have antixenosis or antibiosis effects. In addition, grain brightness may also have a visual effect deterring oviposition.

Conclusions. The most repellent and less favorable varieties for S. zeamais were Tzee-Yellow, Across-Pool, Obatampa and SWAN, that presented high content of phenolics and ferulic acid, hardness and brightness of grains.

Keywords. Zea mays, postharvest decay, pest resistance, attractants, repellents.

Traits morphophysiques et biochimiques impliqués dans la sensibilité variétale des grains au charançon du maïs, Sitophilus zeamais (Coleoptera, Curculionidae)

Description du sujet. Le maïs (Zea mays L.) est un aliment de base fournissant des nutriments aux humains et aux animaux. En Afrique subsaharienne, il est stocké pour assurer l'alimentation durant toute l'année. Cependant, certains ravageurs des denrées stockées, comme le charançon Sitophilus zeamais (Motsch.) (Coleoptera ; Curculionidae), peuvent causer d'énormes pertes.

Objectifs. Cette étude visait à évaluer la préférence de ponte de $S$. zeamais vis-à-vis de variétés de maïs cultivées au Sénégal et l'effet des caractéristiques morphophysiques et biochimiques des grains sur leur sensibilité au ravageur. 
Méthode. Vingt-cinq couples (M/F) de charançons ont été placés au centre d'une arène à égale distance de petits tas de grains $(30 \mathrm{~g})$ de neuf variétés de maïs. L'abondance des adultes sur les tas, la proportion de grains endommagés, la perte de poids en grains et la progéniture adulte ont été confrontés aux caractéristiques des grains (teneur en polyphénols et en acide férulique, dureté, clarté, couleur et taille).

Résultats. La sensibilité des grains au charançon ont varié significativement entre les variétés de maïs. Synth-9243 a été la variété la plus sensible avec plus de grains endommagés $(10,5 \pm 2,3 \%)$, de perte en poids de grains $(2,3 \pm 0,6 \%)$ et de reproduction (17,3 $\pm 3,8$ descendants). Les variétés les moins sensibles étaient across-pool, SWAN, obatampa et tzee-yellow. Les caractéristiques des grains comme la teneur en polyphénols et en acide férulique sont négativement reliées à la sensibilité, mais d'autres constituants pourraient avoir un effet d'antixénose ou d'antibiose. En outre, la clarté des grains pourrait avoir un effet visuel dissuadant la ponte.

Conclusions. Les variétés les moins attractives et moins favorables pour $S$. zeamais étaient tzee-yellow, across-pool, obatampa et SWAN, présentant une teneur élevée en polyphénols et en acide férulique, une forte dureté et clarté des grains.

Mots-clés. Zea mays, maladie post-récolte, résistance aux parasites, attractifs, répulsifs.

\section{INTRODUCTION}

Maize, Zea mays L., is one of the three most important cereal crops worldwide (FAOSTAT, 2018), providing nutrients for humans and animals. It contributes over $20 \%$ of food calories in Africa and Mesoamerica (Shiferaw et al., 2011). In Sahelian Africa, it is mostly used during the lean period (period before new harvest) by many rural communities (Guèye et al., 2008; Adjile, 2012). The adequate storage of maize grains is therefore critical to ensure food resource availability throughout the year (FAO et al., 2015). However, losses (> 20\%) often force resource-poor farmers to sell their maize off cheaply soon after harvest and later to buy food at higher prices (Stephens \& Barrett, 2010; Tefera et al., 2011a). Several factors including insects and rodents, fungal development and synthesis of mycotoxins, contribute to the decrease of grain quantity and quality (Guèye et al., 2011). Among these biotic factors, stored-product insect pests cause the most damage. The two main pests under tropical climate conditions are the maize weevil (Sitophilus zeamais, Motsch.) and the larger grain borer (Prostephanus truncatus, Horn) (Pantenius, 1988; Delobel \& Tran, 1993; Kossou et al., 1993; Bergvinson \& García-Lara, 2004; García-Lara \& Bergvinson, 2007; García-Lara et al., 2019). The maize weevil can cause tremendous losses reaching 40\% in six months (Goergen, 2005; Guèye et al., 2012) along with reduction of grains to dry powder and hulls (Barbercheck, 2020). Larvae develop in grains and damage are usually poorly visible (Barbercheck, 2020). Adults then disperse from granaries to maize fields where they start infesting grains till harvest with dramatic consequences during storage (Abebe et al., 2009). In addition, larval feeding on maize grains reduces germination, and in most cases facilitates secondary contaminations by fungi and bacteria (Marin et al., 2013; Rodriguez-Carrasco et al., 2013). These fungi, particularly Aspergillus flavus, produce carcinogenic substances such as aflatoxins (Delobel \& Tran, 1993; Tefera et al., 2011b; Agriopoulou et al.,
2020) and risks for consumer health and for market of safe food products (Reddy et al., 2010; Williams et al., 2012; Alshannaq \& Yu, 2017).

Pest management mainly relies on the use of chemical insecticides (powdering and fumigation) and hermetical storage in appropriate rooms or containers. However, the continuous use of chemical insecticides has detrimental impact on human health, environmental safety and pest resistance concerns (Isenring, 2010). In addition, most farmers in developing countries cannot afford hermetic storage structures and do not have access to selective and more environment-friendly pesticides due to availability and cost (Midega et al., 2016). In this context, host resistance would be an effective and environmentally safe alternative to reduce postharvest losses in the framework of an integrated pest management strategy (Commission européenne, 2009; FAO, 2012a). Several studies showed some degree of varietal resistance involving physical and biochemical grain characteristics (Peters et al., 1972; Yadu et al., 2000; García-Lara et al., 2004; Abebe et al., 2009; Fourar-Belaifa \& Fleurat-Lessard, 2015). In particular, properties such as grain hardness and content of phenolic acids were reported as factors reducing $S$. zeamais infestations (Serratos et al., 1987; Classen et al., 1990; Arnason et al., 1992; Philogène \& Arnason, 1995; Mwololo et al., 2013; López-Castillo et al., 2018). Knowledge about resistance conferred to maize grain through morphophysical and biochemical traits remains insufficient and more research in this area is necessary to better inform future breeding programs (López-Castillo et al., 2018). Two research hypotheses inspired this work:

- maize varieties have variable susceptibility to maize weevils;

- there are morphophysical or biochemical characteristics that affect susceptibility to $S$. zeamais.

One way to investigate the morphophysical and biochemical traits that can be associated to maize grain resistance or susceptibility is to assess both 
characteristics that may be involved in the interaction between maize and insects, and the evolution of the infestation of grains with such defined characteristics.

Main objectives of the present study were:

- to assess the oviposition preference of S.zeamais over nine maize varieties;

- to identify intrinsic morphophysical and biochemical properties of maize grains that can affect damage and grain losses.

Results are discussed in the light of applied perspectives including integration of new selection criteria on resistance to stored-product pests for maize varieties that have until now been primarily selected for yield (Philogène et al., 1989; Gallo, 2007), and design of new tools for integrated pest management.

\section{MATERIALS AND METHODS}

\subsection{Maize varieties}

Grains harvested from seed field of Senegalese Institute for Agricultural Research (ISRA) were placed in sterilized room under ambient temperature $\left(25-35{ }^{\circ} \mathrm{C}\right)$ and relative humidity $(70-80 \%)$ at seed specialized centers (COPROSA-Nioro du Rip and CNRA-Bambey). Untreated grain samples (Table 1) provided by these seed centers were frozen $\left(-5^{\circ} \mathrm{C}\right)$ for three weeks to eliminate any previous infestation before testing.

\subsection{Insects}

Sitophilus zeamais adults were obtained from the phytosanitary laboratory of the Food Technology Institute (ITA, Dakar, Senegal) in March 2017. Insects were lab-reared on maize grains (HVB1 variety) in our facilities (Entomology and Acarology laboratory,
UCAD-FST, Dakar, Senegal). Glass jars (15 cm height and $8 \mathrm{~cm}$ diameter) were each filled with $250 \mathrm{~g}$ of maize grains, then 50 unsexed adults were introduced into each jar. After 14 days, adults were removed from grains. Infested grains were incubated in an insectarium under ambient temperature $\left(25-35^{\circ} \mathrm{C}\right)$ and relative humidity (70-80\%) until newly adults emerged. Twoday-old adults from the $6^{\text {th }}$ lab-reared generation were used for experiments.

\subsection{Oviposition preference, damage and grain loss}

Oviposition preference of maize weevils was assessed using the emerged progeny from batches of each maize variety. Twenty-five pairs ( 25 males and 25 females) of two-day-old parent adults were placed in the middle of a $30 \mathrm{~cm}$ diameter arena, at equal distance $(5 \mathrm{~cm})$ of small heaps of grains $(30 \mathrm{~g})$ of each tested maize variety (Figure 1). The arena was then covered with lid mesh $(2 \mathrm{~mm})$. Adults present on each maize variety were counted (abundance) and replaced in the center of the arena every $24 \mathrm{~h}$ during 14 days. To assess damage of maize grains, this experimental device was reproduced without disturbing oviposition during 14 days. Then, parent adults were removed from the arena and grains from each variety were placed separately in aerate glass jars with lid mesh $(2 \mathrm{~mm})$ and incubated in the laboratory at ambient temperature $\left(25-35^{\circ} \mathrm{C}\right)$ and $70-80 \%$ relative humidity. Emerged adults were counted daily during 55 days after which grains were sorted into "damaged" and "undamaged" grains. The percentage of grain weight loss was calculated using the Boxal (1986) equation:

$$
\% \text { Weight loss }=\frac{(\mathrm{B} \times \mathrm{E})-(\mathrm{C} \times \mathrm{D})}{(\mathrm{E}(\mathrm{B}+\mathrm{C}))} \times 100
$$

where $\mathrm{B}=$ number of damaged grains, $\mathrm{C}=$ number of undamaged grains, $\mathrm{D}=$ weight of damaged grains, $\mathrm{E}=$ weight of undamaged grains.

Table 1. Characteristics of maize varieties - Caractéristiques des variétés de maïs (FAO, 2012b).

\begin{tabular}{lllllll}
\hline Variety & Genetic nature & $\begin{array}{l}\text { Maturity cycle } \\
\text { (days after sowing) }\end{array}$ & $\begin{array}{l}\text { Potential grain } \\
\text { yield }\left(\mathrm{t} \cdot \mathrm{ha}^{-1}\right)\end{array}$ & Grain type & Grain color & Sample origin \\
\hline SWAN & Composite & $90-100$ & $3-4$ & Horny & Yellow & \\
Early-Thai & Composite & 80 & $2-3$ & Horny & Yellow & COPROSA \\
DMR-ES & Composite & 80 & 2.5 & Horny-toothed & White & Nioro \\
Tzee-Yellow & Composite & $75-80$ & 2 & Horny-toothed & Yellow & \\
Tzee-White & Composite & $75-80$ & 2 & Horny-toothed & White & \\
\hline Synth-9243 & Synthetic & $90-95$ & $3-4$ & Horny-toothed & White & \\
Across-Pool & Composite & $75-80$ & $2-3$ & Horny-toothed & White & CNRA \\
Obatampa & Composite & $95-100$ & 3 & Horny-toothed & White & Bambey \\
Synth-C & Synthetic & 90 & 3.5 & Semi-toothed & White & \\
\hline
\end{tabular}



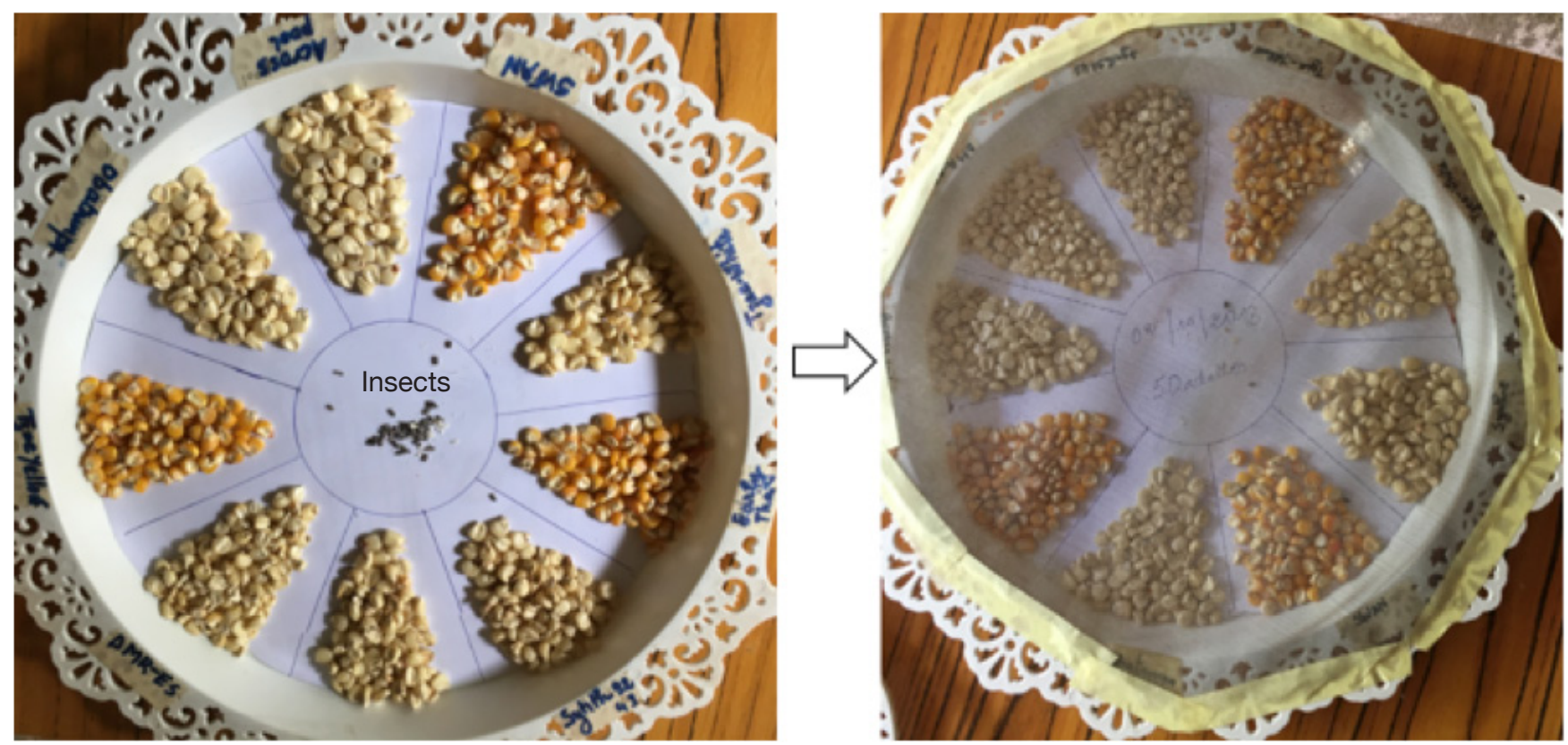

Figure 1. Experimental device for oviposition preference test - Dispositif expérimental pour le test de préférence de ponte.

These experiments were replicated three times with different positioning of maize varieties within the arena.

\subsection{Morphophysical and biochemical grain analyses}

Grain morphophysical and biochemical characteristics were assessed at "General and organic chemistryvolatolomics laboratory" and "TERRA Teaching and Research Center" of Gembloux Agro-Bio Tech (University of Liege, Belgium). Phenolics were first extracted from $1 \mathrm{~g}$ of maize flour using pure methanol under sonication method with three replicates per variety. Methanolic extracts were assayed following recommendations of Bourgou et al. (2016) on colorimetric method with Folin-Ciocalteu reagent described by Singleton \& Rossi (1965). Absorbance was measured by spectrophotometry at $\lambda=760 \mathrm{~nm}$. The content of phenolics was expressed as microgram gallic acid equivalent per gram of dry matter $(\mu \mathrm{g}$ GAE $\left.\mathrm{g}^{-1} \mathrm{DM}\right)$. Qualitative analysis of the phenolic extracts was performed by high-performance liquid chromatography method coupled with a diode array detection (HPLC-DAD) to evaluate ferulic acid content. The HPLC-DAD system was equipped with P-680 pumps, G4212B diode array detector, ASI-100 injector and G1316A thermostated column compartment. Reverse phase chromatographic analysis was carried using Omnispher $3 \mathrm{C}-18$ apolar column (length: $100 \mathrm{~mm}$, particle size: $3 \mu \mathrm{m}$, internal diameter: $3 \mathrm{~mm}$ ). The sample injection volume was $20 \mu$ l. Samples were filtered through membrane filter (pore size $0.45 \mu \mathrm{m}$, Chromafil ${ }^{\circledR}$ Pet-45/15 MS, Macherey-Nagel, Germany) prior to injection in sample loop. Phenolic acids (ferulic and p-coumaric acids) were detected at $\lambda=290, \lambda=310$ and $\lambda=320 \mathrm{~nm}$. Phenolic acids present in samples were identified by comparing chromatographic peaks with retention time of individual standards and further confirmed by co-injection with standard phenolic acids.

To evaluate grain hardness, Stenvert hardness tester (Culatti microhammer mill, Labtech Essa, Belmont, Australia) fitted with a flour sieve and rotating at a speed of 2,500 rpm when empty was used on basis of Pomeranz et al. (1986) and Blandino et al. (2010) methods. The grinding time, considered as the best descriptor of maize grains hardness (Blandino et al., 2010) was used. Time in seconds to collect $20 \mathrm{~g}$ of maize flour through $2 \mathrm{~mm}$ of mesh sieve was recorded from three replicates for each maize variety. Before test, all grain samples were kept at constant temperature $\left(25 \pm 1^{\circ} \mathrm{C}\right)$ in a desiccator for $48 \mathrm{~h}$, to equilibrate grain moisture. Grain size parameters such as length $(\mathrm{L})$, width $(l)$ and thickness $(e)$ were determined on 30 individual grains per variety using a digital caliper (foot to slide) (0.05 $\mathrm{mm}$ precision). Individual grain volume (V) was calculated considering ellipsoidal morphology of grains according to the formula:

$$
\mathrm{V}=\frac{4 \pi}{3}(\mathrm{~L} * l * e)
$$

Grain color parameters were determined using a HunterLab Spectrocolorimeter (Miniscan XE Restor VA 3.5, ColorFlex EZ®), calibrated with a white standard tile. The measurement was carried out on 
whole grains filled in a white cup (45 mm height) of diameter corresponding to the spectrocolorimeter read head. The measurement was repeated six times for each variety. An annular directional $45^{\circ} / 0^{\circ}$ illuminant was used to determine the CIE variables such as $\mathrm{L}^{*}, \mathrm{a}^{*}$ and b* (C.I.E., 1976) at a spectral range of $400 \mathrm{~nm}$ $700 \mathrm{~nm}$. L* denotes lightness or brightness, ranging from zero (black) to 100 (white), $\mathrm{a}^{*}$ and $\mathrm{b}^{*}$ are the opposing color coordinates, with $\mathrm{a}^{*}$ ranging from -60 (green) to +60 (red) and $b^{*}$ ranging from -60 (blue) to +60 (yellow) (Guiné \& Barroca, 2014).

\subsection{Statistical analyses}

Data were analyzed using R software (R-3.0.0 and R-3.4.1, packages ade4, rgl, ggplot2, grid, FactoMineR, devtools, factoextra, mclust, Hmisc, readxl and stats) following recommendations of Bloomfield (2014). Normality assumption and homogeneity of variances were tested using Shapiro-Wilk's test and Bartlett's test, respectively. Given that all series followed normal distribution and had homogeneous variance, the effect of varieties on adult abundance and progeny, damage and grain losses, as well as grains characteristics comparison were performed by one-way analysis of variance (ANOVA) followed by Tukey's HSD (honestly significant difference) test for multiple comparison of means $(5 \%)$.

Correlation matrix (Spearman's correlation) and multivariate analyses such as Principal Component Analysis (PCA) and Factorial Discriminant Analysis
(FDA) were performed to assess the effect of grain morphophysical and biochemical characteristics on host preference of weevil. A variable was considered as Principal Component (PC) when its contribution on one of PCA axes construction was greater than $10 \%$ (average contribution, according to Elbow criterion). The number of factorial axes for PCA was chosen according to Elbow criterion, which enabled to obtain the maximum of inertia with a minimum of factorial axes. The FDA was performed with the PC obtained and used in order to highlight the effect of grain morphophysical and biochemical characteristics on grain susceptibility to $S$. zeamais. A Generalized Linear Model (GLM) was built to examine the effect of some grain characteristics (TPP, L, hardness, and volume) on adult abundance and grain weight loss.

\section{RESULTS}

\subsection{Oviposition preference, damage and grain loss}

Weevils were mainly observed on DMR-ES, Synth9243 and Early-Thai varieties $(3.9 \pm 3.1,3.6 \pm 3.0$ and $3.4 \pm 2.1$ adults $/ 24 \mathrm{~h}$, respectively), but no significant difference $(p>0.05)$ among varieties was observed (Table 2). Females and males adult emergence from grains was significantly affected by variety $(p<0.01)$. The number of adults that emerged from Synth-9243 variety $(17.3 \pm 3.8)$ was higher than that of all other varieties. Adult emergence from Across-Pool, Tzee-

Table 2. Susceptibility of maize varieties to the maize weevil, Sitophilus zeamais - Sensibilité des variétés de maïs au charançon du maïs, Sitophilus zeamais.

\begin{tabular}{lllll}
\hline Variety & Abundance (adults/24h) & TPE (adults/30g) & Damaged grains $(\%)$ & Grain weight loss $(\%)$ \\
\hline Across-Pool & $1.6 \pm 1.3^{\mathrm{a}}$ & $1.0 \pm 0.4^{\mathrm{c}}$ & $2.1 \pm 0.4^{\mathrm{c}}$ & $0.2 \pm 0.1^{\mathrm{c}}$ \\
DMR-ES & $3.9 \pm 3.1^{\mathrm{a}}$ & $7.7 \pm 2.4^{\mathrm{b}}$ & $4.1 \pm 1.9^{\mathrm{b}}$ & $1.0 \pm 0.2^{\mathrm{b}}$ \\
Early-Thai & $3.4 \pm 2.1^{\mathrm{a}}$ & $4.3 \pm 1.5^{\mathrm{b}}$ & $3.5 \pm 1.1^{\mathrm{b}}$ & $0.6 \pm 0.2^{\mathrm{bc}}$ \\
Obatampa & $1.2 \pm 0.2^{\mathrm{a}}$ & $2.0 \pm 0.8^{\mathrm{c}}$ & $2.4 \pm 0.8^{\mathrm{c}}$ & $0.7 \pm 0.2^{\mathrm{bc}}$ \\
SWAN & $0.6 \pm 0.6^{\mathrm{a}}$ & $2.3 \pm 1.5^{\mathrm{c}}$ & $1.8 \pm 0.2^{\mathrm{c}}$ & $0.3 \pm 0.1^{\mathrm{c}}$ \\
Synth-9243 & $3.6 \pm 3.0^{\mathrm{a}}$ & $17.3 \pm 3.8^{\mathrm{a}}$ & $10.5 \pm 2.3^{\mathrm{a}}$ & $2.3 \pm 0.6^{\mathrm{a}}$ \\
Synth-C & $1.2 \pm 1.1^{\mathrm{a}}$ & $4.7 \pm 1.5^{\mathrm{b}}$ & $4.4 \pm 1.3^{\mathrm{b}}$ & $0.8 \pm 0.1^{\mathrm{b}}$ \\
Tzee-White & $1.3 \pm 1.3^{\mathrm{a}}$ & $4.3 \pm 1.8^{\mathrm{b}}$ & $2.4 \pm 0.6^{\mathrm{c}}$ & $0.6 \pm 0.2^{\mathrm{bc}}$ \\
Tzee-Yellow & $0.9 \pm 0.5^{\mathrm{a}}$ & $1.3 \pm 0.2^{\mathrm{c}}$ & $2.1 \pm 0.9^{\mathrm{c}}$ & $0.5 \pm 0.1^{\mathrm{c}}$ \\
\hline$p$ & - & $* * *$ & $* * *$ & $* * *$ \\
\hline ANOVA & $\mathrm{F}_{8.18}=1.58$ & $\mathrm{~F}_{8,18}=42.50$ & $\mathrm{~F}_{8.18}=4.58$ & $\mathrm{~F}_{8.18}=3.05$ \\
\hline
\end{tabular}

ANOVA test: -: not significant, $p \geq 0.05-$ non significatif, $\mathrm{p} \geq 0,05$; ***: highly significant, $p<0.001-$ hautement significatif, $\mathrm{p}<0,001$; means followed by the same letter are not significantly different (Tukey test, $p>0.05$ ) - les moyennes ayant la même lettre ne sont pas significativement différentes (Test de Tukey, $\mathrm{p}>0,05$ ); abundance: mean number of adults observed - nombre moyen d'adultes observés; TPE: total adult progeny emerged from $30 \mathrm{~g}$ grains - progéniture adulte totale émergée des $30 \mathrm{~g}$ de grains; damaged grains: percentage of damaged grains - pourcentage de grains endommagés; grain weight loss: percentage of grain weight loss - pourcentage de perte en poids de grains. 
Yellow, SWAN and Obatampa varieties was the lowest. Damage inflicted to maize grains by maize weevil varied significantly among varieties $(p<0.01)$. SWAN, Tzee-Yellow, Tzee-White, Across-Pool and Obatampa exhibited the lowest proportions of damaged grains and grain weight loss. Conversely, Synth-9243 variety presented greater proportions of damaged grains $(10.5 \pm 2.3 \%)$ and weight loss $(2.3 \pm 0.6 \%)$.

\subsection{Morphophysical and biochemical varietal characteristics of maize grains}

High variation of grain characteristics associated with potential sources of resistance was observed across maize varieties (Table 3). The highest phenolics content was recorded in SWAN and Tzee-White varieties $\left(2,864.2 \pm 121.0\right.$ and $2,405.9 \pm 80.1 \mu \mathrm{g} \mathrm{GAE} \cdot \mathrm{g}^{-1} \mathrm{DM}$, respectively), with quantities two times more than that of Synth-9243 and Obatampa varieties. SWAN, Early-Thai and Tzee-Yellow varieties contained the highest amounts of ferulic acid. The highest crushing time of grains was recorded for SWAN $(21.5 \pm 0.0 \mathrm{~s})$, followed by Tzee-Yellow $(20.7 \pm 0.3 \mathrm{~s})$ then EarlyThai $(20.7 \pm 0.4 \mathrm{~s})$ varieties. Obatampa, Across-Pool, DMR-ES, Tzee-White and Synth-C varieties recorded the highest $\mathrm{L}^{*}$ values and the lowest $\mathrm{b}^{*}$ values (white grains). SWAN, Early-Thai and Tzee-Yellow varieties had the lowest $\mathrm{L}^{*}$ values and highest $\mathrm{b}^{*}$ values (yellow grains). Result of grain individual volume showed that DMR-ES variety has the smallest grain size, while
ynth-C, Obatampa, Across-Pool and SWAN varieties have the largest grains.

\subsection{Relation between varietal characteristics and susceptibility to weevil}

Binary correlations between variables. The abundance of parent adults on grain heaps, as a proxy of oviposition preference, was positively and significantly correlated to the percentage of damaged grains $\left(\right.$ rho $\left.=0.525^{* *}\right)$ and grain weight loss $\left(\right.$ rho $\left.=0.410^{*}\right)$ (Table 4). Emerged progeny was also strongly and positively correlated to grain damage (rho $=0.805^{* * *}$ ) and grain weight loss $\left(\right.$ rho $\left.=0.751^{* * *}\right)$. Damaged grains were positively correlated to weight loss $\left(\right.$ rho $\left.=0.816^{* * *}\right)$ but negatively to phenolics $\left(\mathrm{rho}=-0.513^{*}\right)$. Grain hardness was positively correlated to phenolics content $($ rho $=0.487 *)$, particularly to ferulic acid (rho $=$ $0.698 * * *)$. Grain brightness was negatively correlated to phenolics and ferulic acid contents and hardness, as opposed to yellow color. No significant correlation of volume with either other grain characteristics or infestation was observed.

Generalized linear model. Results of the generalized linear model showed that phenolics content (TPP) of maize grains had a negative effect on the abundance of $S$. zeamais adults on grain heaps and grain weight loss after infestation (Table 5). Grain weight loss also decreased with grain volume.

Table 3. Morphophysical and biochemical characteristics of maize grains - Caractéristiques morphophysiques et biochimiques des grains de maïs.

\begin{tabular}{lllllll}
\hline Variety & $\begin{array}{l}\text { TPP } \\
\left(\mu \mathrm{g} \mathrm{GAE} \cdot \mathrm{g}^{-1} \mathrm{DM}\right)\end{array}$ & $\begin{array}{l}\text { Fer } \\
\left(\mu \mathrm{g} \cdot 100 \mathrm{~g}^{-1} \mathrm{DM}\right)\end{array}$ & $\begin{array}{l}\text { Hardness }(\mathrm{s}) \\
(\text { crushing time })\end{array}$ & $\mathbf{L}^{*}$ & $\mathbf{b}^{*}$ & ${\text { Volume }\left(\mathrm{mm}^{3}\right)}^{\mathrm{a}}$ \\
\hline Across-Pool & $1,461.6 \pm 120.6^{\mathrm{e}}$ & $1,637.3 \pm 28.0^{\mathrm{d}}$ & $18.5 \pm 0.5^{\mathrm{cb}}$ & $70.5 \pm 0.9^{\mathrm{a}}$ & $27.9 \pm 0.8^{\mathrm{c}}$ & $166.1 \pm 17.0^{\mathrm{ab}}$ \\
DMR-ES & $1,297.2 \pm 74.6^{\mathrm{e}}$ & $2,275.5 \pm 127.8^{\mathrm{b}}$ & $17.9 \pm 0.5^{\mathrm{cd}}$ & $69.9 \pm 0.8^{\mathrm{a}}$ & $29.3 \pm 1.1^{\mathrm{c}}$ & $124.5 \pm 5.3^{\mathrm{c}}$ \\
Early-Thai & $1,650.2 \pm 40.3^{\mathrm{d}}$ & $3,205.1 \pm 206.7^{\mathrm{a}}$ & $20.7 \pm 0.4^{\mathrm{a}}$ & $64.0 \pm 0.4^{\mathrm{bc}}$ & $40.3 \pm 1.9^{\mathrm{a}}$ & $148.6 \pm 11.5^{\mathrm{b}}$ \\
Obatampa & $1,111.9 \pm 69.5^{\mathrm{f}}$ & $1,421.1 \pm 256.2^{\mathrm{d}}$ & $14.9 \pm 0.4^{\mathrm{e}}$ & $70.3 \pm 1.2^{\mathrm{a}}$ & $28.9 \pm 0.4^{\mathrm{c}}$ & $176.0 \pm 10.7^{\mathrm{a}}$ \\
SWAN & $2,864.2 \pm 121.0^{\mathrm{a}}$ & $3,011.6 \pm 137.4^{\mathrm{a}}$ & $21.5 \pm 0.0^{\mathrm{a}}$ & $62.9 \pm 1.9^{\mathrm{c}}$ & $40.2 \pm 2.5^{\mathrm{a}}$ & $164.6 \pm 15.2^{\mathrm{ab}}$ \\
Synth-9243 & $1,159.3 \pm 40.2^{\mathrm{f}}$ & $2,066.1 \pm 94.6^{\mathrm{b}}$ & $19.2 \pm 0.2^{\mathrm{b}}$ & $65.4 \pm 1.2^{\mathrm{b}}$ & $28.0 \pm 0.5^{\mathrm{c}}$ & $148.2 \pm 12.9^{\mathrm{b}}$ \\
Synth-C & $1,234.7 \pm 78.7^{\mathrm{ef}}$ & $2,432.3 \pm 316.3^{\mathrm{b}}$ & $18.8 \pm 0.5^{\mathrm{cb}}$ & $68.7 \pm 1.2^{\mathrm{a}}$ & $29.0 \pm 0.5^{\mathrm{c}}$ & $183.5 \pm 10.0^{\mathrm{a}}$ \\
Tzee-White & $2,405.9 \pm 80.1^{\mathrm{b}}$ & $2,357.4 \pm 23.4^{\mathrm{b}}$ & $17.0 \pm 0.3^{\mathrm{d}}$ & $69.6 \pm 0.6^{\mathrm{a}}$ & $32.2 \pm 1.0^{\mathrm{b}}$ & $146.6 \pm 14.9^{\mathrm{b}}$ \\
Tzee-Yellow & $1,793.9 \pm 40.4^{\mathrm{c}}$ & $3,016.9 \pm 216.9^{\mathrm{a}}$ & $20.7 \pm 0.3^{\mathrm{a}}$ & $62.8 \pm 1.2^{\mathrm{c}}$ & $40.7 \pm 2.9^{\mathrm{a}}$ & $142.1 \pm 13.4^{\mathrm{b}}$ \\
\hline$p$ & $* * *$ & $* * *$ & $* * *$ & $* * *$ & $* * *$ & $* * *$ \\
\hline ANOVA & $\mathrm{F}_{8,18}=173.2$ & $\mathrm{~F}_{8,18}=30.2$ & $\mathrm{~F}_{8.18}=85.3$ & $\mathrm{~F}_{8.45}=52.1$ & $\mathrm{~F}_{8.45}=81.9$ & $\mathrm{~F}_{8.261}=8.27$ \\
\hline
\end{tabular}

ANOVA test: $* * *$ : highly significant, $p<0.001$ - hautement significatif, $\mathrm{p}<0,001$; means followed by the same letter are not significantly different (Tukey test, $p>0.05$ ) - les moyennes ayant la même lettre ne sont pas significativement différentes (Test de Tukey, p > 0,05); TPP: total phenolics content of grains - teneur en composés phénoliques des grains; fer: ferulic acid content of grains - teneur en acide férulique des grains; hardness: grain hardness - dureté des grains; DM: dry matter - matière sèche; L*: grain brightness - clarté des grains; $\mathrm{b}^{*}$ : yellow color of grains - couleur jaune des grains; volume: grain volume - taille des grains. 


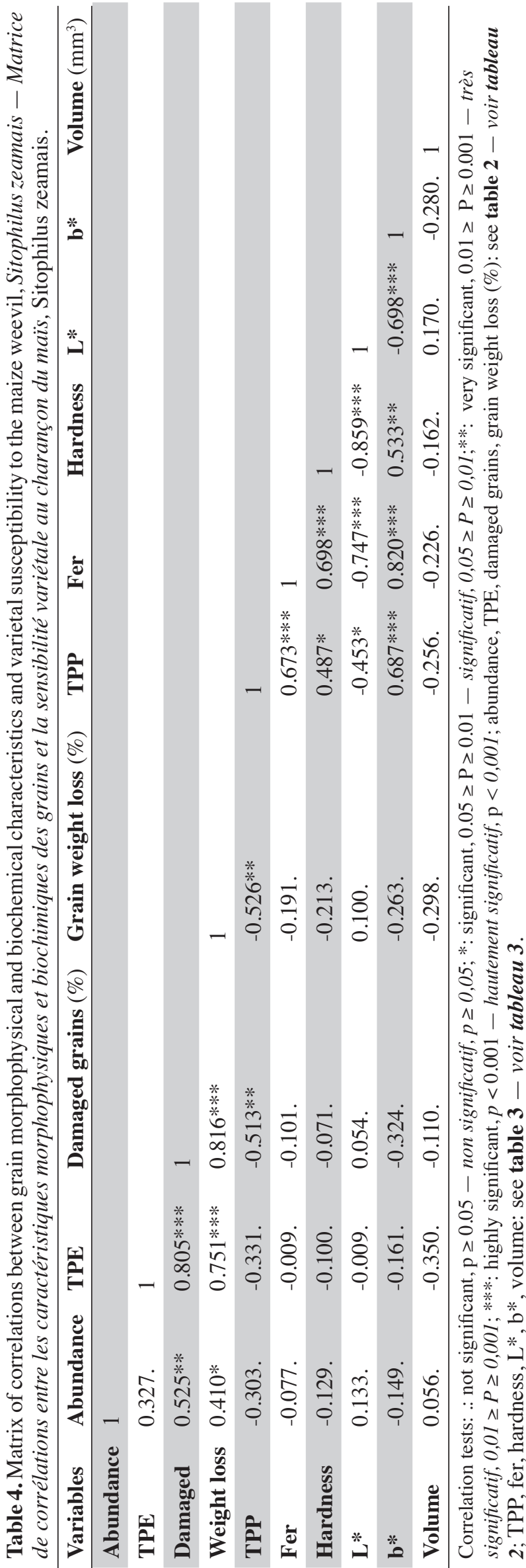

Multivariate analyses of variables. The PCA revealed that the first axis (42.2\% of information) and the second axis (30.3\% of information) with $72.5 \%$ total inertia best explained variability (Figure 2). A positive relationship was observed between total progeny emerged, percentage of damaged grains and grain weight loss. These variables were negatively correlated to phenolics and ferulic acid contents, hardness, and yellow color of grains.

Adult abundance as a proxy for oviposition preference and grain size (volume) had contribution of less than $10 \%$ on PCA axes construction. Therefore, they were not considered as PC and were excluded for the FDA. The FDA conducted with eight PC showed $85.8 \%$ total inertia $(\mathrm{Dim} 1=51.4 \%$ and $\operatorname{Dim} 2=$ $34.4 \%)$. It classified the nine maize varieties into three groups (Figure 3):

- G1: yellow color (high b values), high phenolics and ferulic acid contents and hard grains (not very susceptible and intermediate varieties including SWAN, Tzee-Yellow and Early-Thai varieties);

- G2: low phenolics and ferulic acid contents, low grain brightness (L) and soft grains (most susceptible varieties including Synth-9243);

- G3: low phenolics and ferulic acid contents, high grain brightness, and soft grains (not very susceptible and intermediate varieties including Across-Pool, Tzee-White, Obatampa, Synth-C, and DMR-ES).

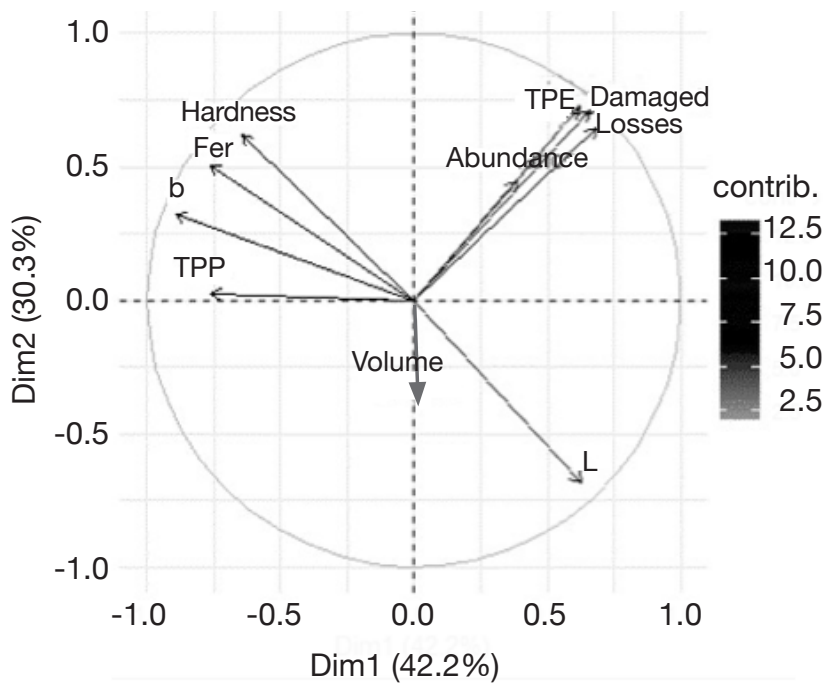

Figure 2. Eigenvalue diagram on PCA of maize grains characteristics - Diagramme des valeurs propres de l'ACP des caractéristiques des grains de maïs.

Principal components are colored from gray to black on PCA graphic according to their contribution level in the two axes - les composantes principales $(P C)$ sont colorées du gris au noir sur le graphique PCA selon leur niveau de contribution dans les deux axes; abundance, TPE, damaged [grains], [grain weight] loss: see table 2 - voir tableau 2 ; TPP, fer, hardness, $\mathrm{L}^{*}, \mathrm{~b}^{*}$, volume: see table 3 - voir tableau 3. 
Table 5. Results of the Generalized Linear Model of abundance of Sitophilus zeamais adults on grain heaps or grain weight loss (\%) according to grain characteristics - Résultats du modèle linéaire généralisé de l'abondance d'adultes de Sitophilus zeamais sur les tas de grains ou de la perte de poids de grain selon les caractéristiques des grains.

\begin{tabular}{llllll}
\hline Dependent variable & $\begin{array}{l}\text { Independent } \\
\text { variable }\end{array}$ & Estimate & Std. Error & t value & $\operatorname{Pr}(>\mathbf{l t} \mathbf{)})$ \\
\hline Abundance (\%) & (Intercept) & -1.523 & 7.554 & -0.20 & 0.840 \\
& TPP & -0.001 & 0.001 & -2.44 & $0.014^{*}$ \\
& Hardness & 0.122 & 0.139 & 0.88 & 0.378 \\
& L & 0.0349 & 0.078 & 0.45 & 0.653 \\
& Volume & -0.007 & 0.007 & -1.08 & 0.281 \\
\hline Grain weight loss (\%) & (Intercept) & 12.368 & 5.931 & 2.08 & 0.048 \\
& TPP & -0.003 & 0.001 & -5.14 & $<0.001^{* * *}$ \\
& Hardness & 0.069 & 0.116 & 0.60 & 0.556 \\
& L & -0.121 & 0.062 & -1.97 & 0.062 \\
& Volume & -0.011 & 0.005 & -2.15 & $0.043^{*}$ \\
\hline
\end{tabular}

Abundance, grain weight loss: see table 2 - voir tableau 2; TPP, hardness, L, Volume: see table 3 - voir tableau 3.

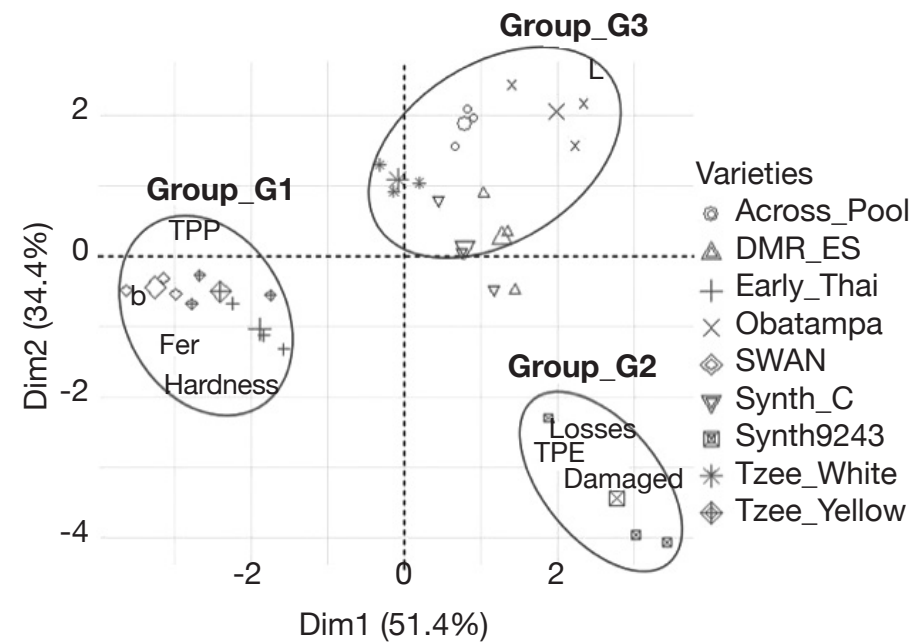

Figure 3. Susceptibility of maize varieties based on grain characteristics (FDA) - Sensibilité des variétés de maïs selon les caractéristiques des grains (FDA).

TPE, damaged [grains], [grain weight] loss: see table 2 - voir tableau 2; TPP, fer, hardness, L, b: see table 3 - voir tableau 3.

\section{DISCUSSION}

\subsection{Maize varietal susceptibility to $S$. zeamais infestation}

Varietal differences of maize grains susceptibility can be explained by antibiosis and antixenosis mechanisms that limit pest infestation (Lopez-Castillo et al., 2018). To understand the factors that are involved in such resistance, susceptibility to maize weevil of grains from nine maize varieties, expressed as visits of adults, emerged progeny and subsequent grain damage and weight loss, was confronted to grain morphophysical and biochemical traits.

The nine tested maize varieties differed in their susceptibility to the maize weevil. The number of adults that emerged from Synth-9243 variety (G2) was greater than that of all other varieties. This suggests that this variety was the most favorable host for S.zeamais. However, Synth-9243 variety had an abundance of 3.6 yet a TPE of 17.3, whereas Early-Thai had abundance of 3.4 but only a TPE of 4.3 . This shows that the abundance of weevils on a maize variety does not necessarily correlates to susceptibility. The high reproductive potential of $S$.zeamais in Synth9243 variety (17.3 of TPE from only $30 \mathrm{~g}$ of grains) should lead to significant economic losses during storage with multiple generations. Indeed, the number of emerged adults was positively correlated to attacks and weight loss of grains, corroborating the earlier findings (García-Lara \& Bergvinson, 2014; Suleiman et al., 2015). No significant difference of adult abundance of maize weevils was observed across varieties, indicating that this was not a major discriminating indicator for varietal susceptibility. Abundance of parent adults was, however, positively and significantly correlated to the percentage of damaged grains and grain weight loss, but not significantly to the adult progeny. This suggests that varietal intrinsic characteristics could influence larval performance. Due to low abundance of weevils on Obatampa (G3), Tzee-Yellow and SWAN (G1), it is possible that these varieties were probably less preferred by insects (less attractive), while AcrossPool (G3) may be less favorable to larval development. 


\subsection{Effect of varietal characteristics on susceptibility}

High variation in traits of maize grains associated to grain preference by insects was recorded across the nine maize varieties. The most infested maize variety, Synth9243 (G2), was characterized by both low phenolics and ferulic acid contents, low grain hardness and moderate brightness (L). Least susceptible varieties such as SWAN and Tzee-Yellow (G1) were characterized by yellow color (high b values), high phenolics and ferulic acid content and hard grains. Phenolics could have deterrent effects on adult egg laying and toxic effects on larvae. Phenolics content was negatively correlated to progeny, damaged grains and grain weight loss. This is in agreement with previous results on negative correlation between maize susceptibility to $S$. zeamais and phenolics content (Serratos et al., 1987; Classen et al., 1990; Arnason et al., 1992). Maize phenolics, ubiquitous in grains at both soluble and bound forms, are essentially composed of two phenolic acids: ferulic and p-coumaric acids. These acids, mostly present in the pericarp and aleurone layer of grains (Adom \& Liu, 2002; De la Parra et al., 2007), are considered good indicators of maize resistance against insects (Kevin, 2002; Santiago \& Malvar, 2010; García-Lara $\&$ Bergvinson, 2014). Maize phenolics are involved in the resistance to both surface tissues formation (antixenose action) and anti-feedants and toxic properties of these free form acids (antibiose action) (Classen et al., 1990; Arnason et al., 1994; GarcíaLara et al., 2004). In maize, antibiosis mechanisms against S. zeamais and Prostephanus truncatus have been found to be closely associated to the action of biochemical compounds such as phenolic acids (Sen et al., 1994; Arnason et al., 1997; López-Castillo et al., 2018; Ngom et al., 2020). Possible inhibition of insect neuroreceptors by phenolic compounds has been suggested by Fixon-Owoo et al. (2003) even if the mechanisms and the determinant of this inhibition are still unknown as well as their association in host insect resistance. Phenolic acid amides localized in aleurone layer cells, such as diferuloylputrescine and di-p-coumaroylputrescine have been also suggested as insect-deterrent compounds (Sen et al., 1994; Arnason et al., 1997; Bily et al., 2003). Maize cell-wall reinforcement by bound from phenolic compounds has been observed to be a complex antixenotic trait, which involves the crosslinking of proteins and esterified cell wall hemicellulose which surround cellulose microfibrils (García-Lara et al., 2004; López-Castillo et al., 2018). This cell-wall reinforcement by some specific phenolic compounds contributes to the increase of the pericarp physical strength and overall grain hardness, representing a challenge for the penetration of maize grains by insect (Abecassis et al., 1997;
López-Castillo et al., 2018). The results are consistent with those of García-Lara et al. (2004), who reported a negative relationship between grain hardness and susceptibility to maize weevil infestation. Ferulic acid, as a major component of phenolics of maize varieties, could be the major factor of resistance, as indicated by previous studies (Philogène \& Arnason, 1995; Bauer et al., 2012; García-Lara \& Bergvinson, 2014). EarlyThai variety (G1) also presented high content of these compounds but suffered from significant grain damage $(3.5 \pm 1.1 \%)$, indicating that other mechanisms might be involved.

Obatampa and Across-pool, the two other least susceptible varieties, showed high grain brightness and soft grains (G3), and relatively low phenolics and ferulic acid contents. Soft grain has been associated with high susceptibility to maize weevil due to easy tunneling and yields huge flour amount for larval feeding (Siwale et al., 2009). Although these varieties had indicators for high susceptibility, other grain characteristics seem to have antixenosis or antibiosis effects. Indeed, grain brightness of these varieties must have a repellent visual effect (negative phototaxis), which limits grain infestation (antixenosis mechanism). Insects may adopt a phototactic response by moving away (negative phototaxis) from grains that have high brightness (De Groote et al., 2017; Kim et al., 2019). Arnold et al. (2015) showed visual stimuli can play a major role in host selection of $S$. zeamais, and indicated that this species was more attracted by colored than bright surfaces. Results showed also that grain weight loss decreased with grain volume, likely as a result of the single-larva development per grain. DMR-ES, second most susceptible variety after Synth9243, had smallest grain size, which seems to attract maize weevil oviposition. This result is in agreement with results of De Groote et al. (2017), which reported that $S$. zeamais infested more small grains than large grains.

\section{CONCLUSIONS}

The most susceptible varieties were Synth-9243 and DMR-ES, and the less susceptible were Across-Pool, SWAN, Obatampa and Tzee-Yellow. The study showed that grain resistance to S.zeamais was particularly related to high phenolics and ferulic acid content, hardness and grain brightness, but it is probable that other chemical constituents may have antixenosis or antibiosis effects. More research on the behavioral response of insects is needed to identify volatile organic compounds involved in repellence, but also bioassays to assess anti-feedant properties and toxicity for larvae. Results could assist selection programs to screen plants for resistance to stored-product pests, but 
also to design repellents that could be used in integrated pest management strategies against $S$.zeamais. With the challenge of food security, nutrition and livelihood in developing countries where the population keeps growing, there is an urgent need to reduce damage from stored-product insect pests. Varietal repellence would be an effective eco-friendly way to minimize postharvest losses and extending shelf-life storage of maize. More research on the behavioral response of insects is needed to identify volatile organic compounds involved in repellence, but also bioassays to assess anti-feedant properties and toxicity of some compounds for larvae.

\section{Bibliography}

Abebe F. et al., 2009. Resistance of maize varieties to the maize weevil Sitophilus zeamais (Motsch.) (Coleoptera: Curculionidae). Afr. J. Biotechnol., 8(21), 5937-5943, doi.org/10.5897/ajb09.821

Abecassis J., Chaurand M. \& Autran J-C., 1997. Structural basis of wheat hardness and technological consequences. Int. Agrophys., 11(4), 273-281.

Adjile A., 2012. Les acquisitions massives de terre agricoles, entre opportunités et menaces pour la paysannerie familiale : étude de cas au Sud et Centre Bénin. Cotonou : CEBEDES.

Adom K.K. \& Liu R.H., 2002. Antioxidant activity of grains. J. Agric. Food Chem., 50(21), 6182-6187, doi. org/10.1021/jf0205099

Agriopoulou S., Stamatelopoulou E. \& Varzakas T., 2020. Advances in occurrence, importance, and mycotoxin control strategies: prevention and detoxification in foods. Foods, 9, 137, doi:10.3390/foods9020137

Alshannaq A. \& Yu J.-H., 2017. Occurrence, toxicity, and analysis of major mycotoxins in food. Int. J. Environ. Res.Public Health, 14, 632, doi:10.3390/ijerph 14060632

Arnason J.T. et al., 1992. Role of phenolics in resistance of maize grain to the stored grain insects, Prostephanus truncatus (Horn) and Sitophilus zeamais (Motsch.). J. Stored Prod. Res., 28(2), 119-126.

Arnason J.T. et al., 1994. Variation in resistance of Mexican landraces of maize to maize weevil Sitophilus zeamais, in relation to taxonomic and biochemical parameters. Euphytica, 74, 227-236, doi.org/10.1007/bf00040405

Arnason J.T. et al., 1997. Mechanism of resistance in maize grain to the maize weevil and the larger grain borer. In: Mihm J.A., ed. Proceedings of an international symposium, Insect resistance maize: recent advances and utilization, 27 November-3 December 1994, CIMMYT, Texcoco, Mexico, 91-95. Texcoco, Mexico: CIMMYT.

Arnold S.E.J., Stevenson P.C. \& Belmain S.R., 2015. Responses to colour and host odour cues in three cereal pest species, in the context of ecology and control. Bull. Entomol. Res., 105(4), 417-425, doi.org/10.1017/ S0007485315000346
Barbercheck M., 2020. Management of stored grain pests in organic systems. Organic Grain Production Resource Book 2020, 182-202.

Bauer J.L., Harbaum-Piayda B. \& Schwarz K., 2012. Phenolic compounds from hydrolyzed and extracted fiber-rich by-products. LWT-Food Sci. Technol., 47(2), 246-254, doi.org/10.1016/j.lwt.2012.01.012

Bergvinson D. \& García-Lara S., 2004. Genetic approaches to reducing losses of stored grain to insects and diseases. Curr. Opin. Plant Biol., 7(4), 480-485, doi.org/10.1016/j. pbi.2004.05.001

Bily A.C. et al., 2003. Dehydrodimers of ferulic acid in maize grain pericarp and aleurone: resistance factors to Fusarium graminearum. Phytopathology, 93(6), 712719, doi.org/10.1094/PHYTO.2003.93.6.712

Blandino M. et al., 2010. Determination of maize kernel hardness: comparison of different laboratory tests to predict dry-milling performance. J. Sci. Food Agric., 90(11), 1870-1878, doi.org/10.1002/jsfa.4027

Bloomfield V.A., 2014. Using $R$ for numerical analysis in science and engineering. Chapman \& Hall/CRC The $\mathrm{R}$ Series.

Bourgou S., Beji R.S., Medini F. \& Ksouri R., 2016. Effet du solvant et de la méthode d'extraction sur la teneur en composés phénoliques et les potentialités antioxydantes d'Euphorbia helioscopia. J. New Sci. Agric. Biotechnol., 28(12), 1649-1655.

Boxal R.A., 1986. A critical review of the methodology for assessing farm-level grain losses after harvest. London: Tropical Development and Research Institute.

C.I.E. (Commission Internationale de l'Éclairage), 1976. Official recommendations on uniform colour spaces, colour differences equations and metric colour terms. Supplement $N^{\circ} 2$ to C.I.E. Publication $N^{\circ} 15$. Paris: C.I.E.

Classen D. et al., 1990. Correlation of phenolic acid content of maize to resistance to Sitophilus zeamais, the maize weevil, in CIMMYT'S collections. J. Chem. Ecol., 16(2), 301-315, doi.org/10.1007/BF01021766

Commission européenne, 2009. Directive 2009/128/CE instaurant un cadre d'action communautaire pour parvenir à une utilisation des pesticides compatibles avec le développement durable. Bruxelles : Commission européenne.

De Groote H. et al., 2017. Maize storage insects (Sitophilus zeamais and Prostephanus truncatus) prefer to feed on smaller maize grains and grains with color, especially green. J. Stored Prod. Res., 71, 72-80, doi.org/10.1016/j. jspr.2017.01.005

De la Parra C., Serna Saldivar S.O. \& Liu R.H., 2007. Effect of processing on the phytochemical profiles and antioxidant activity of corn for production of masa, tortillas, and tortilla chips. J. Agric. Food Chem., 55, 4177-4183, doi.org/10.1021/jf063487p

Delobel A. \& Tran M., 1993. Les coléoptères des denrées alimentaires entreposées dans les régions chaudes. Paris : ORSTOM. 
FAO (Food and Agricultural Organization of the United Nations), 2012a. Catalogue officiel des variétés de maïs. Rome : FAO, http://www.fao.org/pgrfa-gpa-archive/ sen/docs/senegal_varietes/varietes_sen/cereales1.4.pdf, (17/02/2021).

FAO (Food and Agricultural Organization of the United Nations), 2012b. Pertes et gaspillages alimentaires dans le monde-ampleur, causes et prévention. Rome : FAO.

FAO, FIDA \& PAM, 2015. L'état de l'insécurité alimentaire dans le monde 2015. Objectifs internationaux 2015 de réduction de la faim : des progrès inégaux. Rome : FAO.

FAOSTAT, 2018. Production céréalière mondiale, www. fao.org/faostat/fr/\#data/QC/visualize, (15/05/2018).

Fixon-Owoo S. et al., 2003. Preparation and biological assessment of hydroxycinnamic acid amides of polyamines. Phytochemistry, 63(3), 315-334, doi. org/10.1016/S0031-9422(03)00133-X

Fourar-Belaifa R. \& Fleurat-Lessard F., 2015. Susceptibility of some cereal species and cultivars grown in Algeria to post-harvest damage by the rice weevil. Cah. Agric., 24(5), 283-291, doi.org/10.1684/agr.2015.0767

Gallo J., 2007. Crop losses to pests. In: Pimentel D. Encyclopedia of pest management. CRCPress, 60-62.

García-Lara S. \& Bergvinson D.J., 2007. Integral program to reduce post-harvest losses in maize. Agric. Técnica México, 33, 181-189.

García-Lara S. \& Bergvinson D.J., 2014. Phytochemical and nutraceutical changes during recurrent selection for storage pest resistance in tropical maize. Crop Sci., 54(6), 2423-2432, doi.org/10.2135/cropsci2014.03.0223

García-Lara S. et al., 2004. The role of pericarp cell wall components in maize weevil resistance. Crop Sci., 44(5), 1546-1552, doi.org/10.2135/cropsci2004.1546

García-Lara S., García-jaimes E. \& Bergvinson D.J., 2019. Mapping of maize storage losses due to insect pests in central Mexico. J. Stored Prod. Res., 84, 101529, doi. org/10.1016/j.jspr.2019.101529

Goergen G., 2005. Petit manuel d'identification des principaux ravageurs des denrées stockées en Afrique de l'Ouest. Cotonou : INRAB-IITA.

Guèye M.T. et al., 2008. La protection des stocks de maïs au Sénégal: enquêtes sur les pratiques d'utilisation des pesticides et plantes à effet insecticide en milieu paysan. ITA Echos, 3, www.researchgate.net/ publication/287205895, (04/03/3021).

Guèye M.T., Seck D., Wathelet J.P. \& Lognay G., 2011. Lutte contre les ravageurs des stocks de céréales et de légumineuses au Sénégal et en Afrique occidentale: synthèse bibliographique. Biotechnol. Agron. Soc. Environ., 15(1), 183-194.

Guèye M.T., Seck D., Wathelet J. \& Lognay G., 2012. Typologie des systèmes de stockage et de conservation du maïs dans l'Est et le Sud du Sénégal. Biotechnol. Agron. Soc. Environ., 16(1), 49-58.

Guiné R.P.F. \& Barroca M.J., 2014. Quantification of browning kinetics and colour change for quince (Cydonia oblonga Mill.) exposed to atmospheric conditions. Agric. Eng. Int. CIGR J., 16(4), 285-298.

Isenring R., 2010. Les pesticides et la perte de biodiversité. Bruxelles : Pesticide Action Network Europe.

Kevin J.M., 2002. Maize kernel components and their roles in maize weevil resistance. Mexico City: International Center for the Improvement of Wheat and Maize (CIMMYT), www.worldfoodprize.org/documents/ filelibrary/images/youth_programs/2003_interns/ mcnee_8BBD07A320BAC.pdf, (04/03/2021).

Kim K.N., Huang Q.Y. \& Lei C.L., 2019. Advances in insect phototaxis and application to pest management: a review. Pest Manage. Sci., 75(12), 3135-3143, doi. org/10.1002/ps.5536

Kossou D.K., Bosque-Pérez N.A. \& Mareck J.H., 1993. Effets de l'égrenage du maïs sur l'oviposition et le développement du charançon du maïs. J. Stored Prod. Res., 28(3), 187-192.

Marin S., Ramos A., Cano-Sancho G. \& Sanchis V., 2013. Mycotoxins: occurrence, toxicology, and exposure assessment. Food Chem. Toxicol., 60, 218-237.

Midega C.A.O., Murage A.W., Pittchar J.O. \& Khan Z.R., 2016. Managing storage pests of maize: farmers' knowledge, perceptions and practices in western Kenya. Crop Prot., 90, 142-149, doi.org/10.1016/j. cropro.2016.08.033

Mwololo J.K., Mugo S., Tefera T. \& Munyiri S.W., 2013. Evaluation of traits of resistance to postharvest insect pests in tropical maize. Int. J. Agric. Crop Sci., 6(13), 926-933

López-Castillo L.M. et al., 2018. Postharvest insect resistance in maize. J. Stored Prod. Res., 77, 66-76, doi. org/10.1016/j.jspr.2018.03.004

Ngom D. et al., 2020. Varietal susceptibility of maize to larger grain borer, Prostephanus truncatus (Horn) (Coleoptera; Bostrichidae), based on grain physicochemical parameters. PLoS ONE, 15(4), e0232164, doi.org/10.1371/journal.pone.0232164

Pantenius C.U., 1988. Storage losses in traditional maize granaries in Togo. Int. J. Trop. Insect Sci., 9(6), 725-735, doi.org/10.1017/s1742758400005610

Peters L.L., Fairchild M.L. \& Zuber M.S., 1972. Effect of corn endosperm containing different levels of amylose on angoumois grain moth biology. 3. Interrelationship of amylose levels and moisture content of diets. J. Econ. Entomol., 65(4), 1168-1169, doi.org/10.1093/ jee/65.4.1168

Philogène B.J.R. \& Arnason J.T., 1995. La résistance du maïs aux insectes phytophages: une question de molécules. Cah. Agric., 4, 85-90.

Philogène B.J.R., Arnasson J.T. \& Lambert J.D.H., 1989. Facteurs contribuant à la protection du maïs contre les attaques de Sitophilus et Prostephanus. In: Actes du colloque international de technologie, Céréales en régions chaudes : conservation et transformation, 2226 février 1988, Centre universitaire de N'Gaoundéré, 
Cameroun. Paris : Aupelf-Uref ; Eds. John Libbey Eurotext, 141-150.

Pomeranz Y., Hall G.E., Czuchjowska Z. \& Lai F., 1986. Test weight, hardness, and breakage susceptibility of yellow dent corn hybrids. Cereal Chem., 63, 349-351.

Reddy et al.,2010. An overview of mycotoxin contamination in foods and its implications for human health. Toxin Rev., 29(1), 3-26, doi.org/10.3109/15569541003598553

Rodriguez-Carrasco Y., Ruiz M.J., Font G. \& Berrada H., 2013. Exposure estimates to Fusarium mycotoxins through cereals intake. Chemosphere, 93, 2297-2303.

Santiago R.\& Malvar R.A., 2010. Role of dehydrodiferulates in maize resistance to pests and diseases. Int.J. Mol. Sci., 11(2), 691-703, doi.org/10.3390/ijms11020691

Sen A. et al., 1994. Distribution and microchemical detection of phenolic acids, flavonoids, and phenolic acid amides in maize kernels. J. Agric. Food Chem., 42, 1879-1883.

Serratos A. et al., 1987. Factors contributing to resistance of exotic maize populations to maize weevil, Sitophilus zeamais. J. Chem. Ecol., 13(4), 751-762, doi. org/10.1007/BF01020157

Shiferaw B., Prasanna B.M., Hellin J. \& Bänziger M., 2011. Crops that feed the world 6. Past successes and future challenges to the role played by maize in global food security. Food Secur., 3(3), 307-327, doi.org/10.1007/ s12571-011-0140-5

Singleton V.L. \& Rossi J.A. Jr., 1965. Colorimetry of total phenolics with phosphomolybdic-phosphotungstic acid reagents. Am. J. Enol. Vitic., 16(3), 144-158, doi. org/10.12691/ijebb-2-1-5

Siwale J., Mbata K., Mcrobert J. \& Lungu D., 2009. Comparative resistance of improved maize genotypes and landraces to maize weevil. Afr. Crop Sci. J., 17, 1-16
Stephens E.C. \& Barrett C.B., 2010. Incomplete credit markets and commodity marketing behaviour. J. Agric. Econ., 62(1), 1-24, doi: 10.1111/j.14779552.2010.00274.x.

Suleiman R.,Rosentrater K.A.\&Bern C.J.,2015.Evaluation of maize weevils Sitophilus zeamais Motschulsky infestation on seven varieties of maize. J. Stored Prod. Res., 64, 97-102, doi.org/10.1016/j.jspr.2015.09.005

Tefera T., Mugo S. \& Likhayo P., 2011a. Effects of insect population density and storage time on grain damage and weight loss in maize due to the maize weevil Sitophilus zeamais and the larger grain borer Prostephanus truncatus. Afr. J. Agric., 6(10), 2249-2254.

Tefera T. et al., 2011b. The metal silo: an effective grain storage technology for reducing post-harvest insect and pathogen losses in maize while improving smallholder farmers' food security in developing countries. Crop Prot., 30(3), 240-245, doi.org/10.1016/j.cropro.2010.11.015

Williams P.J., Geladi P., Britz T.J. \& Manley M., 2012. Investigation of fungal development in maize kernels using NIR hyperspectral imaging and multivariate data analysis. J. Cereal Sci., 55(3), 272-278, doi. org/10.1016/j.jcs.2011.12.003

Yadu Y.K., Saxena R.C. \& Dubey V.K., 2000. Relative susceptibility of different varieties of maize to infestation by the Sitotroga cerealella (Olivier) as influenced by the biochemical content of the grains. Indian J. Agric. Res., 34(4), 243-246.

(68 ref.) 